\title{
Effect of exposure to Neospora caninum, Salmonella, and Leptospira interrogans serovar Hardjo on the economic performance of Irish dairy herds
}

\author{
E. O’ Doherty, ${ }^{*} \dagger$ R. Sayers, ${ }^{*}$ L. O' Grady, $†$ and L. Shalloo*1 \\ ${ }^{*}$ Teagasc, Animal and Grassland, Research and Innovation Centre, Moorepark, Fermoy, Co. Cork, Ireland \\ †School of Veterinary Medicine, UCD Veterinary Sciences Centre, University College Dublin, Belfield, Dublin 4, Ireland
}

\begin{abstract}
The objective of the current study was to quantify the effects of exposure to Salmonella, Neospora caninum, and Leptospira interrogans serovar Hardjo (L. hardjo) on dairy farm profitability and to simulate the effect of vaccination for Salmonella and L. hardjo on dairy farm profitability. The production effects associated with exposure to each of these pathogens in study herds were defined under 3 categories: (1) milk production effects, (2) reproduction effects (including culling), and (3) mortality effects. The production effects associated with exposure to Salmonella, N. caninum, and L. hardjo were incorporated into the Moorepark Dairy Systems Model. In the analysis, herds negative for exposure to Salmonella, N. caninum, and L. hardjo were assumed baseline herds, with all results presented relative to this base. In simulations examining the effect of vaccination for Salmonella and L. hardjo on farm profitability, vaccinated herds (vaccination costs included) were considered as baseline herds and results were presented relative to this base. Total annual profits in unvaccinated herds were reduced by €77.31, €94.71, and €112.11 per cow at milk prices of $€ 0.24$, €0.29, and $€ 0.34 / \mathrm{L}$, respectively, as a result of exposure to Salmonella. In the current study, herds positive for exposure to Salmonella recorded a 316-kg reduction in milk yield, whereas no association was detected between exposure to $N$. caninum or L. hardjo and milk production. Exposure to both $N$. caninum and $L$. hardjo was associated with compromised reproductive performance. Herds positive for exposure to $N$. caninum and Salmonella had greater rates of adult cow mortality and calf mortality, respectively. Vaccination for both Salmonella and L. hardjo was associated with improved performance in study herds. Exposure to $N$. caninum resulted in a reduction in annual farm profits of €11.55, €12, and €12.44 per cow at each milk price, whereas exposure to L. hardjo resulted in a reduction in annual farm profits of $€ 13.83$,
\end{abstract}

Received March 25, 2014.

Accepted December 30, 2014.

${ }^{1}$ Corresponding author: Laurence.Shalloo@Teagasc.ie
$€ 13.78$, and $€ 13.72$ per cow at each milk price. Herds that tested positive for exposure to Salmonella and $L$. hardjo were compared with herds vaccinated for the respective pathogens. Herds vaccinated for Salmonella generated $€ 67.09$, €84.48, and $€ 101.89$ per cow more profit at each milk price compared with herds positive for exposure. Similarly, herds vaccinated for L. hardjo generated €9.74, €9.69, and €9.63 per cow more profit compared with unvaccinated exposed herds. However, herds that tested negative for exposure to Salmonella and $L$. hardjo generated additional profits of $€ 10.22$ and $€ 4.09$ per cow, respectively, compared with vaccinated baseline herds.

Key words: Salmonella, Neospora caninum, Leptospira interrogans serovar Hardjo (L. hardjo), dairy farm profitability

\section{INTRODUCTION}

Salmonella enterica ssp. enterica serovar Dublin and Salmonella enterica ssp. enterica serovar Typhimurium are the 2 most frequently isolated serovars of Salmonella in cattle (Wray and Sojka, 1977). Salmonella Dublin is host adapted to cattle (Wray and Sojka, 1977). Fecaloral spread is the most common method of Salmonella transmission (Poppe, 2011; Nielsen, 2013). Abortion in the absence of any other clinical signs is associated with infection with Salmonella Dublin (Wray and Sojka, 1977; Poppe, 2011). Previous studies have identified a seasonal pattern in the rate of Salmonella-induced abortions with the incidence of abortions peaking in autumn (Wray and Sojka, 1977). Infection with Salmonella has also been associated a reduction in milk yield in dairy cows (Bazeley, 2006; Nielsen et al., 2012). An increased rate of calf mortality has also been associated with the presence of Salmonella on farms (Taylor et al., 2001; Nielsen et al., 2007).

Neospora caninum is a cyst-forming protozoan parasite, first described in 1988 (Dubey et al., 1988). Dogs and related canids are definitive hosts of $N$. caninum (McAllister et al., 1998; Lindsay et al., 1999), and cattle have been confirmed as intermediate hosts of $N$. caninum. Vertical transmission is the most efficient 
route of $N$. caninum transmission (Dubey et al., 2007). Neospora caninum has a worldwide distribution and numerous studies have identified the pathogen as a major cause of bovine abortion (Anderson et al., 2000). Abortion is the primary clinical sign of $N$. caninum in cattle (Goodswen et al., 2013); abortions induced by $N$. caninum can occur at any time of year but are most common in mo 5 to 8 of pregnancy (Anderson et al., 2000). Clinical manifestations in calves including stillbirth, perinatal mortality, the birth of weak calves, and the birth of calves with neurological disorders have also associated with $N$. caninum infection (McAllister 2007; Brickell et al., 2010). A study by Bartels et al. (2006) identified decreases in milk production and an increased culling risk associated with infection with $N$. caninum. A Canadian study documented an increased rate of services per conception in animals that were seropositive to $N$. caninum (Muñoz-Zanzi et al., 2004).

Cattle are maintenance hosts for leptospires belonging to serovar Hardjo (Leonard et al., 2004; Grooms, 2006). Two types of serovar Hardjo have been identified: Leptospira interrogans serovar Hardjo (type Hardjoprajitno; L. hardjo) and L. borgpetersenii serovar Hardjo (type Hardjo-bovis; Leonard et al., 2004; Grooms, 2006). Urinary shedding is the most efficient method of transmission of $L$. hardjo between cattle (Bearden, 2011), with susceptible cattle becoming infected through ingestion or inhalation of leptospires from the contaminated environment. Leptospires may also persist in the genital tract of cattle, leading to reproductive failure (Grooms, 2006). Leptospira organisms have been found in the semen of bulls and can be transferred to cows during natural service (Bearden, 2011). The clinical manifestations of infections due to leptospirosis in cattle include "milk drop syndrome" and abortion. Milk drop syndrome is characterized by a sudden decrease (drop) or cessation in milk production, with the milk appearing thick, blood tinged, yellow in color, and almost colostrum-like (Ellis et al., 1976; Higgins et al., 1980). Abortion due to L. hardjo can occur several weeks after the initial infection and abortion is often the only clinical manifestation of infection with $L$. hardjo (Radostits, 2000). Abortions associated with $L$. hardjo can occur at any time of the year bur are most common in the third trimester of pregnancy (Radostits, 2000). Infection due to leptospirosis can also result in stillbirths and the birth of weak calves (Bearden, 2011). Previous international studies have identified compromised reproductive performance associated with $L$. hardjo infections on farms (Dhaliwal et al., 1996a,b; Guitian et al., 1999).

Numerous studies worldwide have investigated the economic effects at the farm level of Salmonella, N. caninum, and $L$. hardjo. An investigation of the direct losses associated with infection in $N$. caninum in Canadian dairy herds documented an annual loss of Can $\$ 2,305$ $(€ 1,566)$ per farm for a 50-cow dairy herd (Chi et al., 2002), which equates to a loss of $€ 31$ per cow. Similarly, Pfeiffer et al. (1997) estimated that the annual loss in a 200-cow New Zealand dairy herd due to infection with $N$. caninum was $\mathrm{NZ} \$ 3,900(€ 2,385)$ per herd or $€ 12$ per cow. In a simulation study, the economic loss associated with $N$. caninum in Dutch dairy herds was quantified as $€ 2,053$ per herd (€32/cow) in the first year following an abortion epidemic (Bartels et al., 2006).

With regard to Salmonella, an outbreak in a 100cow dairy herd in the United Kingdom was associated with a $19,430-\mathrm{L}$ reduction in total herd milk output, resulting in a financial loss of $£ 3,600$ or $€ 36$ per cow (Bazeley, 2006). A Danish study examining infection with Salmonella Dublin estimated gross margin losses of $€ 49$ per cow in the year following infection and an average gross margin loss of $€ 8$ per cow in the $10 \mathrm{yr}$ following infection in herds with very good management (Nielsen et al., 2013). However, in herds with very poor management, gross margin losses due to infection with Salmonella Dublin were estimated at $€ 326$ per cow in the year following infection and were on average $€ 188$ per cow in the $10 \mathrm{yr}$ following infection (Nielsen et al., 2013). In another Dutch study, Visser et al. (1997) documented an average of Dfl. (Dutch florins) 55 (€23) per cow due to infection with Salmonella Dublin in 40 Dutch dairy herds. Although fewer studies are available on L. hardjo, one study by Bennett (1993) estimated an annual loss of $£ 6,000(€ 7,000)$ due to leptospirosis infection in a 100-cow dairy herd in the United Kingdom, which equates to a loss of $€ 70$ per cow.

It is evident from the studies presented here that infection with Salmonella, N. caninum, and L. hardjo can cause significant economic losses on dairy farms. However, limited information is available on the economic effect of these pathogens in Irish dairy herds. Irish dairying is based on an extensive, pasture-based system of livestock production, operating at a stocking rate of, on average, 1.9 livestock units (LU) per hectare (Dillon, 2011). Such systems involve calving cows to coincide with the period of maximum grass growth; that is, spring (Dillon et al., 1995), with cows being fed grazed grass outdoors for up to $235 \mathrm{~d}$ of lactation (Drennan et al., 2005). However, limited information exists on the economic effect of these pathogens in such pasture-based dairy production systems Irish dairy herds. The results of this study can therefore be compared with studies in countries where confinement systems of dairy production predominate.

The abolition of the European Union milk production quotas in 2015 presents an opportunity for Irish dairy farmers to increase milk production for the first time in 
a generation (Shalloo et al., 2012; Quinlan, 2013). This potential can only be realized if the losses associated with infectious diseases, including but not exclusively those caused by Salmonella, N. caninum, and L. hardjo, are minimized, ensuring the productivity and sustainability of the Irish dairy industry. Heretofore, the costs associated with exposure to Salmonella, N. caninum, and $L$. hardjo in Irish dairy herds and the effect of exposure to these pathogens on the profitability of Irish dairy herds have not being quantified. The objective of this study was to quantify the costs associated with exposure to Salmonella, N. caninum, and L. hardjo in unvaccinated Irish dairy herds. In addition, we quantified the effect of vaccination for Salmonella and $L$. hardjo on farm profitability compared with herds that tested positive and negative for exposure to Salmonella, N. caninum, and L. hardjo.

\section{MATERIALS AND METHODS}

\section{Herd-Level Antibody Status Classification}

Classification of herd-level exposure status to Salmonella, $N$. caninum, and $L$. hardjo has been described in detail in O' Doherty et al. (2013), which investigated temporal trends in bulk milk antibody levels of these pathogens in Irish dairy herds. Briefly, bulk milk samples were collected from 312 study herds at 4 time points in 2009 (March, June, August, and November) and were tested for antibodies against Salmonella, N. caninum, and $L$. hardjo using commercially available ELISA kits. Information on the vaccination protocols for Salmonella and $L$. hardjo were collected using farmer-declared survey data. The ELISA test results and vaccination status of each herd were combined to determine the antibody status (test negative vs. test positive) of study herds. Herds were classified as vaccinated or unvaccinated for Salmonella and L. hardjo based on the survey information. No vaccine for $N$. caninum is licensed for use in Ireland. Unvaccinated herds were classified as negative for exposure to each respective pathogen if the herd recorded a negative bulk milk antibody reading at all of the 4 sampling time points in 2009 (O' Doherty et al., 2013); that is, if a herd recorded at least one positive bulk milk reading in 2009, it was classified as positive for exposure to the respective pathogen.

\section{Production Effects}

The production losses associated with exposure to Salmonella, N. caninum, and L. hardjo have been documented by O' Doherty (2014). These production losses were defined under 3 categories: (1) milk production losses, (2) reproductive performance (including culling) losses, and (3) mortality losses.

\section{Milk Production Losses}

Linear fixed-effect models in PROC GLM of SAS (version 9.1, SAS Institute Inc., Cary, NC) were used to quantify the associations between both bulk milk antibody status of Salmonella, N. caninum, and L. hardjo and vaccination status for Salmonella and $L$. hardjo with herd level milk yield, fat yield, protein yield, and SCS (geometric mean SCC). Production parameters were included in the model as dependent variables and disease or vaccination status as independent variables. Fixed effects included herd size, average parity, proportion of Holstein-Friesian animals, average economic breeding index value, and median calving date in 2009 . Unvaccinated herds positive for exposure to Salmonella produced $316 \mathrm{~kg}$ less milk compared with unvaccinated negative herds. No association was detected between exposure to $N$. caninum or L. hardjo and milk production. Herds vaccinated for Salmonella and L. hardjo had SCC that were $20 \times 10^{3}$ and $28 \times 10^{3}$ cells $/ \mathrm{mL}$ lower, respectively, compared with SCC in unvaccinated herds.

\section{Reproductive Performance Losses}

Linear fixed-effect models were used to determine the association between disease and vaccination status for Salmonella, N. caninum, and L. hardjo with reproductive performance variables, including herd-level 42-d calving rate (i.e., the number of primiparous and multiparous cows that calved in the first 6 wk of the calving season as a proportion of the total number of primiparous and multiparous cows that calved throughout the entire calving season), calving spread, calving interval (i.e., the average number of days between successive calvings for cows that calved in both 2009 and 2010), percentage of calves per cow per year (i.e., the number of calves that were alive at $28 \mathrm{~d}$ that were born to cows in the herd on June 30), replacement rate (i.e., the number of first-calving cows in the herd as a proportion of all cows in the herd), culling rate (i.e., the number of cows sold, sent to abattoir or died as a proportion of all cows in the herd on June 30), percentage of cows not in calf (i.e., the number of cows in the herd that did not have a calf in 2009 or 2010 as a proportion of all cows in the herd), and the percentage of carryover cows in study herds (i.e., the number of cows that calved during the previous calving season but did not calve during the subsequent calving season and were not culled, as a proportion of all cows in the herd). Fixed effects in the models included average economic breeding index val- 
ue, proportion of Holstein-Friesian animals, herd size, and average parity. Models that included the variable calves per cows per year as a dependent variable were also controlled for the variable herd-level replacement rate. Herds positive for exposure to $N$. caninum had a 6-d-longer calving interval, a 10-d increase in calving spread in primiparous cows, and produced $4 \%$ fewer calves per cow per year compared with negative herds. Unvaccinated herds positive for exposure to Salmonella produced $3 \%$ fewer calves per cow per year compared with unvaccinated negative herds. Unvaccinated herds positive for exposure to $L$. hardjo had a $12 \%$ lower 42 -d calving rate and a $8 \%$ higher rate of carryover cows and produced $9 \%$ fewer calves per cow per year compared with unvaccinated negative herds. Herds vaccinated for L. hardjo had a $5 \%$ higher 42 -d calving rate and a $3 \%$ lower rate of empty cows, and produced $3 \%$ more calves per cow per year compared with unvaccinated herds.

\section{Mortality Rates}

Linear fixed-effect models were also used to quantify the association between antibody and vaccination status (as independent variables) for Salmonella, N. caninum, and $L$. hardjo with neonatal mortality, young-calf mortality, and adult cow mortality (dependent variables). Models were adjusted for herd size in 2009, and models with adult cow mortality as dependent variables were adjusted for parity in 2009. Herds positive for exposure to $N$. caninum had an $8 \%$ greater rate of adult cow mortality compared with negative herds. Unvaccinated herds positive for exposure to Salmonella had a 1.5\% greater rate of calf mortality compared with unvaccinated negative herds, whereas herds vaccinated for Salmonella had a $1.14 \%$ greater rate of calf mortality compared with unvaccinated herds.

\section{Economic Analysis}

Production data (Tables 1, 2, and 3) were incorporated into the Moorepark Dairy Systems Model (MDSM; Shalloo et al., 2004) to simulate the effect of exposure to each pathogen on farm net profitability. In addition, the economic impact of vaccination for Salmonella and L. hardjo was simulated using the MDSM. The MDSM is a stochastic budgetary simulation model of a dairy farm. The MDSM integrates animal inventory and valuation, milk production, feed requirement, land and labor utilization, and economic analysis. The MDSM allows investigation of the effects of varying biological, technical, and physical processes on farm profitability. Variable costs (fertilizer, contractor charges, medical and veterinarian, AI, silage, and reseeding), fixed costs (machinery maintenance and running costs, farm maintenance, car, telephone, electricity, and insurance) and all farm receipts (milk, cull cow, and calf) were based on current costs and prices (Table 4; Teagasc, 2013). Land area assumed in the model was 40 ha, with cow numbers fixed at 100 cows. Concentrate usage was fixed at $390 \mathrm{~kg}$ of DM/cow. Full labor costs were included in the model, with 1 labor unit costing $€ 22,855$. The MDSM assumed that all male calves were sold and replacements were reared off-farm from birth. The model uses the net energy system (Jarrige, 1989) to calculate feed requirements for milk production, maintenance, pregnancy, and BW change. The profitability effects associated with exposure to the 3 pathogens were calculated across 3 base milk prices of $€ 0.24$, €0.29, and $€ 0.34 / \mathrm{L}$, assuming a reference milk content of $36.0 \mathrm{~g}$ of fat $/ \mathrm{kg}$ and $33.0 \mathrm{~g}$ of protein $/ \mathrm{kg}$ (i.e., the reference used by the majority of Irish dairy manufacturers; Geary et al., 2012). Calf and cull cow values were based on average prices, with cull cows valued at $€ 400$ and male calves valued at $€ 100$ at 1 mo of age. Vaccination costs were included for Salmonella and $L$. hardjo in the model at $€ 7.25$ and $€ 3.50$ per dose, respectively, for the herds that stated that they used vaccines. We assumed that vaccines were administered in accordance with manufacturer guidelines in the model. Annual tuberculosis and brucellosis costs and routine animal treatment costs were included in the model. Artificial insemination costs were estimated using 1.7 inseminations per conception, costing €25.40 and a service charge of $€ 11.43$. The key default parameters included in the model are shown in Table 4. Outputs from the MDSM include physical outputs such as feed budget, nutrient balance sheet, and financial indicators (e.g., operating cash flow, profit and loss account, and balance sheet). Incorporating the biological data associated with exposure to Salmonella, N. caninum, and L. hardjo had an effect on milk receipts, feed demand, labor, and livestock movement components within the model for both vaccinated and unvaccinated herds.

\section{Scenarios}

Two scenarios were investigated to allow examination of the effect of exposure to Salmonella, $N$. caninum, and L. hardjo in unvaccinated herds and to allow examination of the effect of vaccination for Salmonella and $L$. hardjo compared with herds that tested both positive and negative for exposure to these pathogens.

- Scenario 1 included unvaccinated herds only. Herds negative for exposure to each pathogen (Salmonella, N. caninum, and L. hardjo) were assumed as baseline herds, and the results generated 
Table 1. Milk production losses associated with exposure to Neospora caninum, Salmonella, and Leptospira interrogans serovar Hardjo (L. hardjo) in study herds

\begin{tabular}{|c|c|c|c|}
\hline Pathogen & $\begin{array}{l}\text { Difference } \\
\text { in LSM }\end{array}$ & $P$-value & Source \\
\hline N. caninum (negative vs. positive herds) & & & O' Doherty (2014) \\
\hline No associations identified & - & - & \\
\hline $\begin{array}{l}\text { Salmonella } \\
\text { Negative vs. positive herds (unvaccinated herds only) }\end{array}$ & & & O’ Doherty (2014) \\
\hline $\begin{array}{l}\text { Negative vs. positive herds (unvaccinated herds only) } \\
\text { Milk yield, } \mathrm{kg}\end{array}$ & 316 & 0006 & \\
\hline Fat yield, kg & 14 & 0.003 & \\
\hline Protein yield, kg & 12 & 0.003 & \\
\hline $\begin{array}{l}\text { Unvaccinated vs. vaccinated herds } \\
\text { SCC }, \times 10^{3} \text { cells } / \mathrm{mL}\end{array}$ & 20 & 0.04 & \\
\hline L. hardjo & & & O' Doherty (2014) \\
\hline $\begin{array}{l}\text { Negative vs. positive herds (unvaccinated herds only) } \\
\text { No associations identified }\end{array}$ & - & - & \\
\hline $\begin{array}{l}\text { Unvaccinated vs. vaccinated herds } \\
\text { SCC, } \times 10^{3} \text { cells } / \mathrm{mL}\end{array}$ & 28 & 0.01 & \\
\hline
\end{tabular}

Table 2. Reproductive performance losses associated with exposure to Neospora caninum, Salmonella, and Leptospira interrogans serovar Hardjo (L. hardjo) in study herds

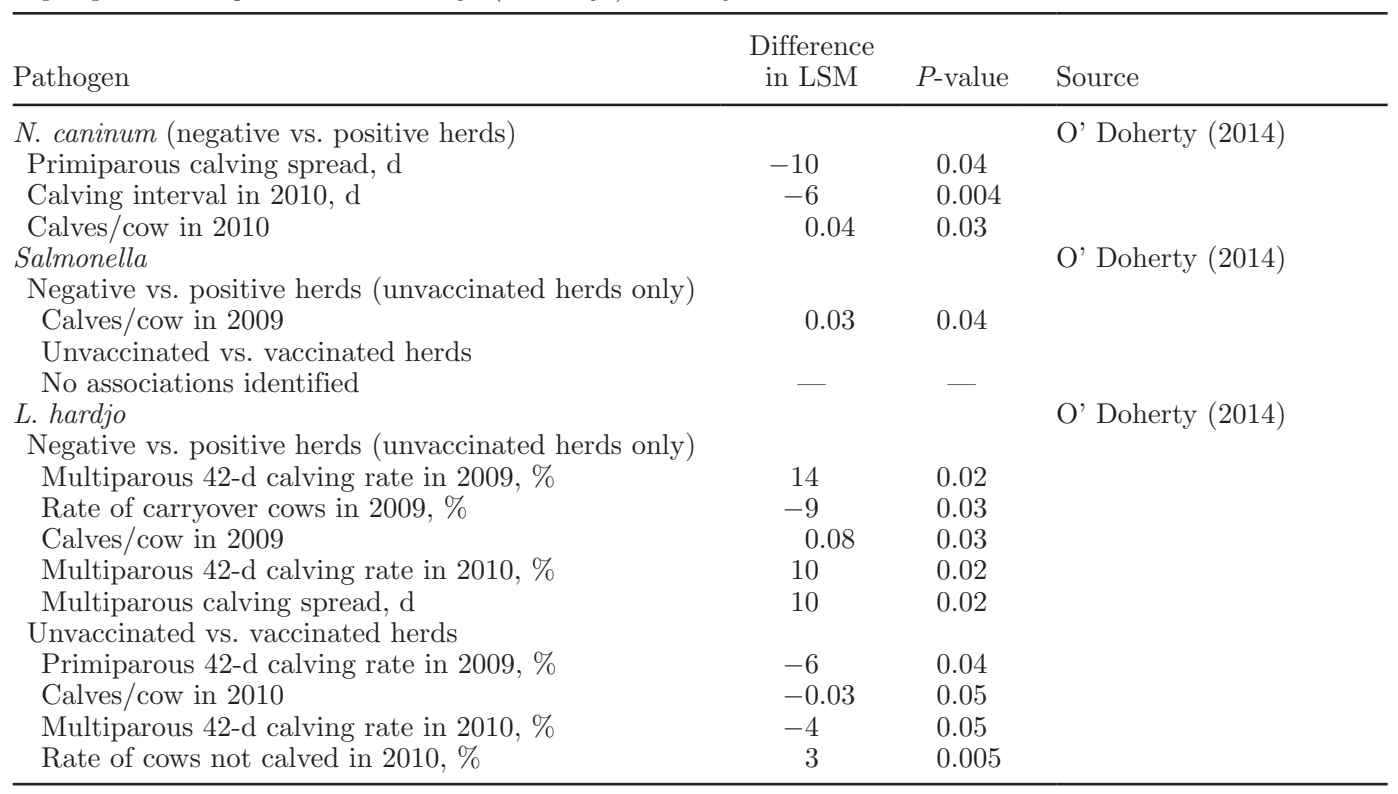

Table 3. Mortality losses associated with exposure to Neospora caninum, Salmonella, and Leptospira interrogans serovar Hardjo (L. hardjo) in study herds

\begin{tabular}{|c|c|c|c|}
\hline Pathogen & $\begin{array}{l}\text { Difference in } \\
\text { LSM }\end{array}$ & $P$-value & Source \\
\hline N. caninum (negative vs. positive herds) & & & O' Doherty (2014) \\
\hline Adult cow mortality in $2009, \%$ & -8 & 0.05 & \\
\hline \multicolumn{4}{|l|}{ Salmonella } \\
\hline Negative vs. positive herds (unvaccinated herds only) & & & O' Doherty (2014) \\
\hline Young-calf mortality in $2009, \%$ of calves born & -1.5 & 0.01 & \\
\hline Unvaccinated vs. vaccinated herds & & & \\
\hline Neonatal mortality in $2009, \%$ calves born & -1.14 & 0.007 & \\
\hline L. hardjo & & & \\
\hline Negative vs. positive herds (unvaccinated herds only) & & & O’ Doherty (2014) \\
\hline Unvaccinated vs. vaccinated herds & & & \\
\hline No associations identified & - & - & \\
\hline
\end{tabular}


Table 4. Default herd parameters in the Moorepark Dairy Systems Model

\begin{tabular}{lc}
\hline Parameter & Value \\
\hline Farm size, ha & 40 \\
Concentrate cost, $€ / \mathrm{t}$ & 270 \\
Fertilizer cost, $€ / \mathrm{t}$ & \\
Calcium ammonium nitrate & 300 \\
Urea & 380 \\
Replacement rate, $\%$ & 19 \\
Replacement heifer cost, $€$ & 1,540 \\
Cull cow value, $€ /$ head & 400 \\
Male calf value $€ /$ head & 100 \\
\hline
\end{tabular}

by unvaccinated test-positive herds were presented relative to this base.

- Scenario 2. Salmonella and L. hardjo vaccinated herds were compared with unvaccinated positive herds and negative herds. Vaccinated herds were assumed as baseline herds, and the results generated by both unvaccinated test-positive herds and unvaccinated test-negative herds were presented relative to this base. This scenario aimed to assess whether vaccinated herds delivered a greater economic performance compared with an unvaccinated herd that was either positive or negative.

Profitability was estimated for the farm as a whole, on a per cow basis, and per kilogram of milk produced.

\section{RESULTS}

\section{N. caninum}

Herds positive for exposure to $N$. caninum produced $27 \mathrm{~kg}(0.5 \%)$ less milk per cow per year compared with the (negative-herd) baseline (Table 5). The volume of milk sold was $2,474 \mathrm{~kg}(0.5 \%)$ lower in $N$. caninum test-positive herds compared with the baseline herd. Replacement costs were $€ 558$ greater in $N$. caninum test-positive herds compared with the baseline. Herds positive for exposure to $N$. caninum generated total costs that were $€ 932$ greater compared with the baseline (Table 6). Herds positive for exposure to N. caninum generated milk receipts that were equal in value to the negative baseline (Table 6). Total profits per farm were $€ 1,155$, $€ 1,200$, and $€ 1,244$ lower compared with the baseline in herds positive for exposure to $N$. caninum based on milk prices of $€ 0.24$, €0.29, and $€ 0.34 / \mathrm{L}$, respectively (Table 6). At a milk price of $€ 0.29 / \mathrm{L}$, farm profits in herds positive for exposure to $N$. caninum were reduced by $€ 12$ per cow and $€ 0.002$ per kg compared with the negative baseline.

\section{Salmonella}

Scenario 1. Unvaccinated Salmonella positive herds had a $316 \mathrm{~kg}(6 \%)$ lower 305 -d milk yield per cow compared with the baseline (unvaccinated negative herds; Table 5). Consequently, these positive herds generated a $31,411 \mathrm{~kg}(6 \%)$ lower volume of milk sales and 2,369 $\mathrm{kg}(6 \%)$ less milk solid sales. Total costs generated by unvaccinated herds that tested positive for exposure to Salmonella were $€ 633$ lower compared with the negative baseline (Table 7). Unvaccinated herds that tested positive for exposure to Salmonella generated milk receipts that were $€ 8,423, € 10,152$, and $€ 11,800$ lower at milk prices of €0.24, €0.29, and €0.34/L compared with the negative baseline (Table 7). In unvaccinated herds positive for exposure to Salmonella, total profits per farm were reduced by $€ 7,731$, €9,471, and €11,211 compared with the negative baseline based on milk

Table 5. Effect of exposure to Neospora caninum, Salmonella, and Leptospira interrogans serovar Hardjo (L. hardjo) and vaccination status for Salmonella and L. hardjo on the physical outputs of a simulated 100-cow dairy herd

\begin{tabular}{|c|c|c|c|c|c|c|}
\hline Physical output & \multicolumn{6}{|c|}{ Exposure and vaccination status } \\
\hline Land area, ha & 40.5 & 40.6 & 39.22 & 40.8 & 40.5 & 40.7 \\
\hline Cows calving, no & 100 & 100 & 100 & 100 & 100 & 100 \\
\hline Stocking rate, $\mathrm{LU}^{3} / \mathrm{ha}$ & 2.37 & 2.36 & 2.45 & 2.35 & 2.37 & 2.36 \\
\hline Milk solids, $\mathrm{kg}$ & 37,646 & 37,632 & 35,277 & 37,742 & 37,652 & 37,712 \\
\hline Grass, $\mathrm{kg}$ of $\mathrm{DM} / \mathrm{cow}$ & 3,661 & 3,627 & 3,517 & 3,595 & 3,661 & 3,626 \\
\hline Grass silage, $\mathrm{kg}$ of DM/cow & 1,131 & 1,181 & 1,123 & 1,223 & 1,131 & 1,181 \\
\hline Concentrate, $\mathrm{kg}$ of DM/cow & 398 & 398 & 398 & 398 & 398 & 398 \\
\hline
\end{tabular}

${ }^{1}$ Bulk milk antibody positive.

${ }^{2}$ Comprises both negative and positive herds.

${ }^{3}$ Livestock units. 
Table 6. Economic effect of exposure to Neospora caninum in a simulated 100 -cow dairy herd at 3 potential milk prices (€0.24, €0.29, and $€ 0.34$ per liter)

\begin{tabular}{|c|c|c|}
\hline \multirow[b]{2}{*}{$\begin{array}{l}\text { Financial } \\
\text { output }\end{array}$} & \multicolumn{2}{|c|}{$\begin{array}{l}\text { Exposure status } \\
\text { to } N \text {. caninum }\end{array}$} \\
\hline & $\begin{array}{l}\text { Negative } \\
\text { (baseline) }\end{array}$ & Positive $^{1}$ \\
\hline \multicolumn{3}{|l|}{ Costs, € } \\
\hline Labor & 29,193 & 29,102 \\
\hline Replacements & 29,245 & 29,803 \\
\hline Total & 155,425 & 156,357 \\
\hline \multicolumn{3}{|l|}{ Milk receipts, $€$} \\
\hline at $€ 0.24 / \mathrm{L}$ & 133,941 & 133,872 \\
\hline at $€ 0.29 / \mathrm{L}$ & 161,425 & 161,317 \\
\hline at $€ 0.34 / \mathrm{L}$ & 188,908 & 188,762 \\
\hline \multicolumn{3}{|l|}{ Profit } \\
\hline \multicolumn{3}{|l|}{ Profit/cow, $€$} \\
\hline at $€ 0.24 / \mathrm{L}$ & 58 & 46 \\
\hline at $€ 0.29 / \mathrm{L}$ & 334 & 322 \\
\hline at $€ 0.34 / \mathrm{L}$ & 611 & 599 \\
\hline \multicolumn{3}{|c|}{ Profit/kg of milk, $€ \mathrm{c}$} \\
\hline at $€ 0.24 / \mathrm{L}$ & 1.13 & 0.91 \\
\hline at $€ 0.29 / \mathrm{L}$ & 6.55 & 6.35 \\
\hline at $€ 0.34 / \mathrm{L}$ & 11.96 & 11.78 \\
\hline \multicolumn{3}{|c|}{ Total profit/farm, $€$} \\
\hline at $€ 0.24 / \mathrm{L}$ & 5,784 & 4,629 \\
\hline at $€ 0.29 / \mathrm{L}$ & 33,445 & 32,245 \\
\hline at $€ 0.34 / \mathrm{L}$ & 61,105 & 59,861 \\
\hline
\end{tabular}

${ }^{1}$ Bulk milk antibody positive. prices of $€ 0.24, € 0.29$, and $€ 0.34 / \mathrm{L}$, respectively (Table 7). At a milk price of $€ 0.29 / \mathrm{L}$, farm profits per cow and per kilogram of milk were reduced by €94.71 and $€ 0.016$, respectively, in herds positive for exposure to Salmonella compared with the negative baseline.

Scenario 2. Relative to vaccinated herds, unvaccinated herds that tested positive for exposure to Salmonella had a 316-kg (6\%) lower 305-d milk yield per cow (Table 5). Consequently, unvaccinated Salmonella test-positive herds generated milk sales that were $31,411 \mathrm{~kg}$ lower and milk solids that were 2,369 $\mathrm{kg}$ lower compared with the vaccinated baseline. We detected no difference in physical outputs between unvaccinated herds negative for exposure to Salmonella and vaccinated herds (Table 5). Total costs generated by unvaccinated herds that tested positive for exposure to Salmonella were $€ 2,099$ lower than that of the vaccinated baseline (Table 7). Unvaccinated herds negative for exposure to Salmonella generated total costs that were $€ 1,376$ lower compared with the vaccinated baseline (Table 7). Milk receipts in unvaccinated Salmonella positive herds were $€ 8,423$, €10,152, and $€ 11,800$ lower compared with the vaccinated baseline based on milk prices of $€ 0.24, € 0.29$, and $€ 0.34 / \mathrm{L}$ (Table 7 ). Herds negative for exposure to Salmonella generated milk receipts that were equal in value to those of vaccinated baseline herds (Table 7). Unvaccinated herds that tested positive for exposure to Salmonella generated total

Table 7. Economic effect of exposure to and vaccination for Salmonella in a simulated 100-cow dairy herd at 3 potential milk prices $(€ 0.24, € 0.29$, and $€ 0.34$ per liter $)$

\begin{tabular}{|c|c|c|c|c|}
\hline \multirow[b]{2}{*}{$\begin{array}{l}\text { Financial } \\
\text { output }\end{array}$} & \multicolumn{4}{|c|}{ Exposure status to Salmonella } \\
\hline & $\begin{array}{l}\text { Negative } \\
\text { (baseline) }\end{array}$ & $\begin{array}{l}\text { Unvaccinated } \\
\text { positive }^{1}\end{array}$ & $\begin{array}{l}\text { Vaccinated } \\
\text { (baseline) }\end{array}$ & Unvaccinated $^{2}$ \\
\hline \multicolumn{5}{|l|}{ Costs, $€$} \\
\hline Labor & 29,193 & 29,193 & 29,193 & 29,193 \\
\hline Replacements & 29,245 & 29,244 & 29,244 & 29,244 \\
\hline Total & 155,425 & 154,792 & 156,801 & 155,425 \\
\hline \multicolumn{5}{|l|}{ Milk receipts, $€$} \\
\hline at $€ 0.24 / \mathrm{L}$ & 133,941 & 125,518 & 133,941 & 133,960 \\
\hline at $€ 0.29 / \mathrm{L}$ & 161,425 & 151,273 & 161,425 & 161,447 \\
\hline at $€ 0.34 / \mathrm{L}$ & 188,908 & 177,028 & 188,908 & 188,935 \\
\hline \multicolumn{5}{|l|}{ Profit } \\
\hline \multicolumn{5}{|l|}{ Profit/cow, $€$} \\
\hline at $€ 0.24 / \mathrm{L}$ & 58 & -19 & 48 & 47 \\
\hline at $€ 0.29 / \mathrm{L}$ & 334 & 240 & 324 & 323 \\
\hline at $€ 0.34 / \mathrm{L}$ & 611 & 499 & 601 & 600 \\
\hline \multicolumn{5}{|c|}{ Profit/kg of milk, $€ \mathrm{c}$} \\
\hline at $€ 0.24 / \mathrm{L}$ & 1.13 & -0.41 & 0.93 & 0.91 \\
\hline at $€ 0.29 / \mathrm{L}$ & 6.55 & 5.00 & 6.35 & 6.33 \\
\hline at $€ 0.34 / \mathrm{L}$ & 11.96 & 10.41 & 11.76 & 11.75 \\
\hline \multicolumn{5}{|c|}{ Total profit/farm, $€$} \\
\hline at $€ 0.24 / \mathrm{L}$ & 5,784 & $-1,947$ & 4,762 & 4,663 \\
\hline at $€ 0.29 / \mathrm{L}$ & 33,445 & 23,974 & 32,422 & 32,328 \\
\hline at $€ 0.34 / \mathrm{L}$ & 61,105 & 49,894 & 60,083 & 59,992 \\
\hline
\end{tabular}


Table 8. Economic effect of exposure to and vaccination for Leptospira interrogans serovar Hardjo (L. hardjo) in a simulated 100 -cow dairy herd at 3 potential milk prices (€0.24, €0.29, and €0.34 per liter)

\begin{tabular}{|c|c|c|c|c|}
\hline \multirow[b]{2}{*}{$\begin{array}{l}\text { Financial } \\
\text { output }\end{array}$} & \multicolumn{4}{|c|}{ Exposure status to L. hardjo } \\
\hline & $\begin{array}{l}\text { Negative } \\
\text { (baseline) }\end{array}$ & $\begin{array}{l}\text { Unvaccinated } \\
\text { positive }^{1}\end{array}$ & $\begin{array}{l}\text { Vaccinated } \\
\text { (baseline) }\end{array}$ & Unvaccinated $^{2}$ \\
\hline \multicolumn{5}{|l|}{ Costs, $€$} \\
\hline Labor & 29,193 & 29,193 & 29,193 & 29,193 \\
\hline Replacements & 29,245 & 29,244 & 29,244 & 29,244 \\
\hline Total & 155,425 & 156,209 & 156,188 & 156,278 \\
\hline \multicolumn{5}{|l|}{ Milk receipts, $€$} \\
\hline at $€ 0.24 / \mathrm{L}$ & 133,941 & 134,206 & 133,941 & 134,160 \\
\hline at $€ 0.29 / \mathrm{L}$ & 161,425 & 161,705 & 161,425 & 161,664 \\
\hline at $€ 0.34 / \mathrm{L}$ & 188,908 & 189,205 & 188,908 & 189,168 \\
\hline \multicolumn{5}{|l|}{ Profit } \\
\hline \multicolumn{5}{|l|}{ Profit/cow, $€$} \\
\hline at $€ 0.24 / \mathrm{L}$ & 58 & 44 & 54 & 49 \\
\hline at $€ 0.29 / \mathrm{L}$ & 334 & 321 & 330 & 325 \\
\hline at $€ 0.34 / \mathrm{L}$ & 611 & 597 & 607 & 602 \\
\hline \multicolumn{5}{|c|}{ Profit/kg of milk, $€ \mathrm{c}$} \\
\hline at $€ 0.24 / \mathrm{L}$ & 1.13 & 0.87 & 1.05 & 0.87 \\
\hline at $€ 0.29 / \mathrm{L}$ & 6.55 & 6.32 & 6.47 & 6.32 \\
\hline at $€ 0.34 / \mathrm{L}$ & 11.96 & 11.77 & 11.88 & 11.77 \\
\hline \multicolumn{5}{|c|}{ Total profit/farm, $€$} \\
\hline at $€ 0.24 / \mathrm{L}$ & 5,784 & 4,401 & 5,375 & 4,867 \\
\hline at $€ 0.29 / \mathrm{L}$ & 33,445 & 32,067 & 33,036 & 32,542 \\
\hline at $€ 0.34 / \mathrm{L}$ & 61,105 & 59,733 & 60,696 & 60,217 \\
\hline
\end{tabular}

profits per farm that were $€ 6,709, € 8,488$, and $€ 10,189$ lower than the vaccinated baseline based on milk prices of $€ 0.24$, €0.29, and €0.34/L, respectively (Table 7 ). Compared with vaccinated herds, unvaccinated herds positive for exposure to Salmonella generated €84.48 per cow and a $€ 0.014 / \mathrm{kg}$ of milk lower profit (Table 7 ) at a milk price of $€ 0.29 / \mathrm{L}$. Herds negative for exposure to Salmonella generated a total profit per farm that was $€ 1,022$ greater based on milk prices of $€ 0.24$, €0.29, and $€ 0.34 / \mathrm{L}$ compared with the vaccinated baseline (Table 7). Profits per cow were $€ 10.22$ greater and profits per kilogram of milk were $€ 0.002$ higher in herds negative for exposure to Salmonella relative to the vaccinated baseline (Table 7 ).

\section{Hardjo}

Scenario 1. Unvaccinated herds that tested positive for exposure to L. hardjo recorded a $31 \mathrm{~kg}(0.6 \%)$ lower 305-d milk yield per cow compared with the baseline (Table 5). Consequently, the total quantity of milk sold across the herd was 2,543 $\mathrm{kg}$ less (0.5\%). However, unvaccinated herds that tested positive for exposure to $L$. hardjo generated $96 \mathrm{~kg}(0.3 \%)$ greater volume of milk solids compared with the baseline due to an increase in milk solids concentrations (Table 5). Unvaccinated herds that tested positive for exposure to $L$. hardjo generated total costs that were $€ 784$ greater compared with the negative baseline (Table 8). Unvaccinated herds that tested positive for exposure to $L$. hardjo generated milk receipts that were equal in value to that of the negative baseline (Table 8). Unvaccinated herds positive for exposure to $L$. hardjo generated total profits per farm that were $€ 1,383$, €1,378, and $€ 1,372$ lower compared with the negative baseline, based on milk prices of $€ 0.24, € 0.29$, and $€ 0.34 / \mathrm{L}$, respectively (Table 8). At a milk price of $€ 0.29 / \mathrm{L}$, farm profits in herds positive for exposure to $L$. hardjo were reduced by $€ 13.78$ per cow compared with the negative baseline. On a profit per kilogram of milk basis, profits in herds positive for exposure to $L$. hardjo were reduced by $€ 0.023 / \mathrm{kg}$ relative to negative herds at a milk price of $€ 0.29 / \mathrm{L}$.

Scenario 2. Unvaccinated herds positive for exposure to L. hardjo had a 305-d milk yield $31 \mathrm{~kg}$ lower than that of the vaccinated baseline (Table 5). We detected no difference in the physical performance of unvaccinated herds that were negative for exposure to $L$. hardjo compared with that of the vaccinated baseline (Table 5). Total costs in unvaccinated herds that tested positive for exposure to $L$. hardjo were equal to those of the vaccinated herds (Table 8). Unvaccinated herds negative for exposure to $L$. hardjo generated total costs that were $€ 763$ lower compared with that of the vaccinated baseline (Table 8 ). Unvaccinated $L$. hardjopositive herds generated milk receipts that were equal 
in value to that of the vaccinated baseline (Table 8). Herds negative for exposure to $L$. hardjo generated milk receipts that were equal to that of the vaccinated baseline (Table 8). Unvaccinated herds that tested positive for exposure to $L$. hardjo generated total profits per farm that were €969 lower at a milk price of €0.29/L compared with the vaccinated baseline (Table 8). Relative to vaccinated herds, unvaccinated herds positive for exposure to $L$. hardjo generated $€ 9.69$ less profit per cow and $€ 0.002 / \mathrm{kg}$ of milk lower profit at a milk price of $€ 0.29 / \mathrm{L}$ (Table 8). Herds negative for exposure to $L$. hardjo generated total profits per farm that were $€ 409$ greater at each milk price compared with the vaccinated baseline (Table 8). Profits were $€ 4.09 /$ cow and $€ 0.002 / \mathrm{kg}$ greater in herds negative for exposure to $L$. hardjo compared with the vaccinated baseline at a milk price of $€ 0.29 / \mathrm{L}$ (Table 8).

\section{DISCUSSION}

The objectives of the present study were to simulate the economic implications associated with exposure to $N$. caninum, Salmonella, and L. hardjo in Irish dairy herds and then to simulate the association between exposure to these pathogens and farm profitability. In addition, the effect of vaccination against Salmonella and $L$. hardjo on farm profitability was quantified when compared with both unvaccinated test-positive and test-negative herds. Farm profitability was reduced in unvaccinated herds having evidence of exposure to Salmonella, N. caninum, and L. hardjo. The analysis suggested that vaccination had a positive influence on farm profitability compared with unvaccinated herds that tested positive for exposure to Salmonella and $L$. hardjo. However, herds vaccinated for Salmonella and L. hardjo had lower profits compared with negative herds. The losses reported in the present study most likely reflect the losses associated with endemic infection (i.e., a low incidence over lactation and persistently elevated bulk milk antibody readings over the entire lactation; O' Doherty et al., 2013) and thus provide important information on the long-term adverse effects of exposure to these pathogens on performance in dairy herds. The implementation of suitable control programs is therefore necessary to prevent economic losses from occurring. Herds negative for exposure to Salmonella, $N$. caninum, and L. hardjo may have implemented biosecurity measures to maintain a negative disease status, which may have incurred a financial cost. However, herds negative for exposure to these pathogens generated greater profits than herds that tested positive for exposure. A cost-benefit analysis is therefore necessary to determine those control measures that deliver the optimum economic benefit when implemented in positive herds.

\section{N. caninum}

Neospora caninum can result in a longer calving interval (Williams et al., 2000; Macaldowie et al., 2004; O' Doherty, 2014). Evans et al. (2006), Shalloo et al. (2014), and Geary et al. (2012) have shown that longer calving intervals are associated with lower 305-d milk yields. Increased calving intervals will result in cows spending more days in late lactation and more days dry, with a subsequent reduction in milk yield (Patton, 2012). The results of the present study support these findings, with $N$. caninum-positive herds recording a milk yield that was $27 \mathrm{~kg}$ lower. Additionally, the later mean calving date (because of the longer calving interval) will reduce the amount of grazed grass in the diet (Shalloo et al., 2014). As grass silage is 2.8 times more expensive than grazed grass (Finneran et al., 2010), the increased use of grass silage contributed to the increased total costs associated with exposure to $N$. caninum in the current study. Increased replacement costs due to the $8 \%$ increase in adult cow mortality $\left(\mathrm{O}^{\prime}\right.$ Doherty, 2014) also contributed to higher total costs in exposed herds.

Previous studies have documented annual losses of between $€ 31$ and $€ 50$ associated with infection with $N$. caninum in Canadian and Dutch dairy herds, respectively (Chi et al., 2002; Bartels et al., 2006). In the present study, total farm profits in herds that tested positive for exposure to $N$. caninum were reduced by $€ 12$ per cow. The difference in losses between studies may be, in part, because the costs associated with $N$. caninum-induced abortions were included in the Canadian and Dutch dairy studies, whereas no information was available on the number of abortions in herds in the current study (O' Doherty, 2014). The greater losses reported in the Dutch study may have resulted from the inclusion of herds with a history of abortion due to $N$. caninum, whereas the present study examined losses associated with exposure to $N$. caninum. In addition, the associations documented in the current study are based on actual study herd data (O' Doherty, 2014), whereas some values used by Chi et al. (2002) were based on estimated values. Finally, the Irish system of dairy farming is predominantly pasture-based with spring calving, which is different from the confinement systems in other countries, this also may have resulted in the differences in the figures among international studies. Regardless of study differences, exposure to $N$. caninum has been shown to result in reduced farm profitability, losses that may persist in a herd over 
many years due to efficient vertical transmission of the parasite from infected dam to fetus. Herd diagnosis and subsequent control of $N$. caninum is necessary, therefore, and it is important to highlight the potential economic effect of this pathogen at the farm level to achieve effective control.

\section{Salmonella}

Exposure to Salmonella in unvaccinated herds in the present study was associated with substantial financial losses. The reductions in profits per cow in the present study as a result of exposure to Salmonella are in agreement with those in the study by Nielsen et al. (2013), who documented average gross margin losses of $€ 8$, €84, €163, and €188 per cow across 4 management types; very good management, good management, poor management, and very poor management over a $10-y r$ period in Danish dairy herds. Even though the management level of herds in the present study was not included in the model, the annual losses reported in this study (i.e., €94/cow) were similar to those recorded in herds with a good level of management in the Danish study, even though no fixed costs were included in that study. The simulation outputs of the present study suggest that, at a milk price of $€ 0.24 / \mathrm{L}$, the reduction in farm profits in test-positive herds would result in dairy farmers operating at a loss under Irish conditions. Prolonged periods of low milk price could therefore lead to unsustainable losses on farms without suitable contingencies in place. An investigation by O' Doherty et al. (2013) documented a prevalence of bulk milk antibodies to Salmonella of $49 \%$ in Irish dairy herds. As those herds were geographically representative of the national population of dairy farmers (O' Doherty et al., 2013), exposure to Salmonella is common in Ireland. Since the removal of European market supports in 2005, Irish dairy producers have been exposed to fluctuating milk prices. The importance of implementing suitable control measures for Salmonella species, therefore, should not be underestimated, and focused research on Salmonella prevention and control in Irish dairy herds is urgently required.

\section{L. hardjo}

Exposure to L. hardjo was associated with an increase in total costs in the current study. Exposure to $L$. hardjo was associated with compromised reproductive performance and an increased rate of carryover cows (O' Doherty, 2014). Carryover cows require additional feed resources, leading to increased costs (Butler et al., 2010). A higher rate of carryover cows would also result in a reduction in milk yield because such animals spend more days in late lactation or dry, thereby contributing to the lower milk yield evident among $L$. hardjo-positive herds. The reduction in the 42 -d calving rate associated with exposure to L. hardjo also leads to increased calving spread and related reductions in milk yield similar to the situation outlined for $N$. caninum.

Exposure to L. hardjo resulted in a reduction of total farm profits of $€ 1,378$ at a milk price of $€ 0.29 / \mathrm{L}$, equating to $€ 14$ per cow. A study by Bennett (1993) documented a loss of $€ 70$ per cow in the first year following introduction of $L$. hardjo in a UK dairy herd, which is higher than the loss reported in the present study. Several factors might have contributed to the apparent discrepancy in losses between these studies. First, the losses reported by Bennett (1993) relate to introduction of $L$. hardjo, whereas the current study did not record infection dates, with data more probably reflecting endemic infection, as described previously. Infection with $L$. hardjo has been associated with the reduction in milk yield known as milk drop syndrome (Ellis et al., 1976; Higgins et al., 1980) and, as such, Bennett (1993) included losses due to reduced milk production when estimating the cost of the leptospirosis outbreak. In the current study, however, no such association was detected between milk production and exposure to $L$. hardjo (O' Doherty, 2014), which may account for the lower losses in the present study compared with the UK study. Nonetheless, herds exposed to L. hardjo will incur a reduction in farm profitability, and mechanisms of control will be of benefit to infected herds.

\section{Vaccination}

In the present study, herds vaccinated for Salmonella recorded superior profits to unvaccinated positive herds to a value of $€ 8,448$ ( $€ 84.48 / \mathrm{cow})$. Similar to vaccination for Salmonella, unvaccinated herds that tested positive for exposure to $L$. hardjo generated $€ 970$ (i.e., $€ 9.70 /$ cow) lower total farm profits compared with vaccinated herds. This finding is of considerable importance in promoting the control of Salmonella and L. hardjo in Ireland and highlights the benefits to be gained from vaccination in positive herds. In addition, herds negative for exposure to both Salmonella and $L$. hardjo generated greater profits compared with vaccinated herds, suggesting that avoiding exposure to these pathogens offers the greatest economic benefit to dairy farmers. However, no information is available on the costs associated with maintaining a disease-free status in herds that tested negative for exposure, and followup studies examining the cost benefit of controlling these pathogens are required. 


\section{CONCLUSIONS}

Exposure to Salmonella, N. caninum, and L. hardjo resulted in significant financial losses for Irish dairy farmers. The reduction in total farm profits because of exposure to Salmonella in unvaccinated herds was between 3 and 4 times greater than the combined reduction in farm profits associated with exposure to $N$. caninum and $L$. hardjo. The calculation of farm profitability as profit per cow and as profit per kilogram of milk in the present study will aid individual dairy producers in estimating the economic effect of exposure to the pathogens under investigation in their own herds, not only in Ireland but also in other regions with similar systems of dairy production. The greater profitability among vaccinated Salmonella and L. hardjo herds compared with unvaccinated test-positive herds highlights the potential role of vaccination in future control programs, whereas the greater profit in the testnegative herds suggests that the optimal solution is to avoid disease exposure.

\section{REFERENCES}

Anderson, M. L., A. G. Andrianarivo, and P. A. Conrad. 2000. Neosporosis in cattle. Anim. Reprod. Sci. 60-61:417-431.

Bartels, C. J. M., H. Hogeveen, G. Van Schaik, W. Wouda, and T. Dijkstra. 2006. Estimated economic losses due to Neospora caninum infection in dairy herds with and without a history of Neospora caninum associated abortion epidemics. Page 228 in Proc. 11th Symp. Int. Soc. Vet. Epidemiol. Econ., Cairns, Australia.

Bazeley, K. 2006. An outbreak of Salmonellosis in a Somerset dairy herd. UK Vet. Livest. 11:42-46.

Bearden, H. J. 2011. Infectious diseases: Leptospirosis. Pages 181-183 in Encyclopedia of Dairy Science J. W. Fuquay, ed. Elsevier Ltd., New York, NY.

Bennett, R. M. 1993. Decision support models of leptospirosis in dairy herds. Vet. Rec. 132:59-61.

Brickell, J. S., M. M. McGowan, and D. C. Wathes. 2010. Association between Neospora caninum seropositivity and perinatal mortality in dairy heifers at first calving. Vet. Rec. 167:82-85.

Butler, S. T., L. Shalloo, and J. J. Murphy. 2010. Extended lactations in a seasonal-calving pastoral system of production to modulate the effects of reproductive failure. J. Dairy Sci. 93:1283-1295.

Chi, J., J. A. VanLeeuwen, A. Weersink, and G. P. Keefe. 2002. Direct production losses and treatment costs of bovine viral diarrhoea virus, bovine leukosis virus, Mycobacterium avium subspecies paratuberculosis and Neospora caninum. Prev. Vet. Med. 55:137-153.

Dhaliwal, G. S., R. D. Murray, H. Dobson, J. Montgomery, and W. A. Ellis. 1996a. Reduced conception rates in dairy cattle associated with serological evidence of Leptospira interrogans serovar hardjo infection. Vet. Rec. 139:110-114.

Dhaliwal, G. S., R. D. Murray, and W. A. Ellis. 1996b. Reproductive performance of dairy herds infected with Leptospira interrogans serovar hardjo relative to the year of diagnosis. Vet. Rec. 138:272-276.

Dillon, P. 2011. The Irish dairy industry - Planning for 2020. Pages 1-24 in Proc. Teagasc National Dairy Conference. The Irish dairy industry: To 2015 and beyond. November 2011, Cork, Ireland. Accessed Jan. 10, 2014. http://ww.teagasc.ie/publications.viewpublication.apx?publicaionid $=1054$.

Dillon, P., S. Crosse, G. Stakelum, and F. Flynn. 1995. The effect of calving date and stocking rate on the performance of springcalving dairy cows. Grass Forage Sci. 50:286-299.
Drennan, M. J., A. F. Carson, and S. Crosse. 2005. Overview of animal performance from pastures in Ireland. Pages 19-36 in Utilisation of Grazed Grass in Temperate Animal Systems. J. J. Murphy, ed. Wageningen Academic Publishers, Wageningen, the Netherlands.

Dubey, J. P., J. L. Carpenter, C. A. Speer, M. J. Topper, and A. Uggla. 1988. Newly recognized fatal protozoan disease of dogs. J. Am. Vet. Med. Assoc. 192:1269-1285.

Dubey, J. P., G. Schares, and L. M. Ortega-Mora. 2007. Epidemiology and control of neosporosis and Neospora caninum. Clin. Microbiol. Rev. 20:323-367.

Ellis, W. A., J. J. O'Brien, J. K. L. Pearson, and D. S. Collins. 1976. Bovine leptospirosis: Infection by the Hebdomadis serogroup and mastitis. Vet. Rec. 99:368-370.

Evans, R. D., M. Wallace, L. Shalloo, D. J. Garrick, and P. Dillon. 2006. Financial implications of recent declines in reproduction and survival of Holstein-Friesian cows in spring-calving Irish dairy herds. Agric. Syst. 89:165-183.

Finneran, E., P. Crosson, L. Shalloo, D. Foristal, P. O' Kiely, and M. Wallace. 2010. Simulation modelling of the cost of producing and utilising feeds for ruminants on Irish farms. J. Farm Manage. 14:95-116.

Geary, U., N. Lopez-Villalobos, N. Begley, F. McCoy, B. O' Brien, L. O' Grady, and L. Shalloo. 2012. Estimating the effect of mastitis on the profitability of Irish dairy farms. J. Dairy Sci. 95:36623673 .

Goodswen, S. J., P. J. Kennedy, and J. T. Ellis. 2013. A review of the infection, genetics and evolution of Neospora caninum: From the past to the present. Infect. Genet. Evol. 13:133-150.

Grooms, D. L. 2006. Reproductive losses caused by bovine viral diarrhea virus and leptospirosis. Theriogenology 66:624-628.

Guitian, J., M. C. Thurmond, and S. K. Hietala. 1999. Infertility and abortion among first lactation dairy cows seropositive or seronegative for Leptospira interrogans serovar hardjo. J. Am. Vet. Med. Assoc. 215:515-518.

Higgins, R. J., J. F. Harbourne, T. W. A. Little, and A. E. Stevens. 1980. Mastitis and abortion in dairy cattle associated with Leptospira of the serotype hardjo. Vet. Rec. 107:307-310.

Jarrige, R., ed. 1989. Ruminant Nutrition, Recommended Allowances and Feed Tables. John Libbey Eurotext, Montrouge, France.

Leonard, N., J. F. Mee, S. Snijders, and D. Mackie. 2004. Prevalence of antibodies to Leptospira interrogans serovar hardjo in bulk tank milk from unvaccinated Irish dairy herds. Ir. Vet. J. 57:226-231.

Lindsay, D. S., J. P. Dubey, and R. B. Duncan. 1999. Confirmation that the dog is a definitive host for Neospora caninum. Vet. Parasitol. 82:327-333.

Macaldowie, C., S. W. Maley, S. Wright, P. Bartley, I. Esteban-Redondeo, D. Buxton, and E. A. Innes. 2004. Placental pathology associated with fetal death in cattle inoculated with Neospora caninum by two different routes in early pregnancy. J. Comp. Pathol. 131:142-156.

McAllister, M. M. 2007. Bovine neosporosis and coccidiosis. Biologico Sao Paulo 69:57-61.

McAllister, M. M., J. P. Dubey, D. S. Lindsay, W. R. Jolley, R. A. Wills, and A. M. McGuire. 1998. Dogs are definitive hosts of Neospora caninum. Int. J. Parasitol. 28:1473-1478.

Muñoz-Zanzi, C. A., M. C. Thurmond, and S. K. Hietala. 2004. Effect of bovine viral diarrhoea virus infection on fertility of dairy heifers. Theriogenology 61:1085-1099.

Nielsen, L. R. 2013. Review of pathogenesis and diagnostic methods of immediate relevance for epidemiology and control of Salmonella Dublin in cattle. Vet. Microbiol. 162:1-9.

Nielsen, L. R., B. Van Den Borne, and G. van Schaik. 2007. Salmonella Dublin infection in young dairy calves: transmission parameters estimated from field data and an SIR-model. Prev. Vet. Med. 79:46-58.

Nielsen, T. D., L. E. Green, A. B. Kudahl, S. Ostergaard, and L. R. Nielsen. 2012. Evaluation of milk yield losses associated with Salmonella antibodies in bulk tank milk in bovine dairy herds. J. Dairy Sci. 95:4873-4885.

Nielsen, T. D., A. B. Kudahl, S. Ostergaard, and L. R. Nielsen. 2013. Gross margin losses due to Salmonella Dublin infection in Danish 
dairy cattle herds estimated by simulation modelling. Prev. Vet. Med. 111:51-62.

O' Doherty, E. 2014. Biological and economic impact of non-regulatory infectious diseases in Irish dairy herds. PhD Thesis. National University of Dublin, Dublin, Ireland.

O' Doherty, E., R. Sayers, and L. O' Grady. 2013. Temporal trends in bulk milk antibodies to Salmonella, Neospora caninum, and Leptospira interrogans serovar hardjo in Irish dairy herds. Prev. Vet. Med. 109:343-348.

Patton, J. 2012. The economics of recycled cows and extended lactations. Paper presented at the Teagasc National Liquid Milk Event 2012, Wexford, Ireland. Accessed Jan. 29, 2013. http://www. teagasc.ie/publications/2012/1581/index.asp.

Pfeiffer, D. U., N. B. Williamson, and R. N. Thornton. 1997. A simple spread sheet simulation model of the economic effects of Neospora caninum abortions in dairy cattle in New Zealand. Pages 10.12.110.12.3 in Proc. 8th Symp. Int. Soc. Vet. Epidemiol. Econ., Paris, France.

Poppe, C. 2011. Infectious diseases: Salmonellosis. Pages 190-194 in Encyclopedia of Dairy Science. J. W. Fuquay, ed. Elsevier Ltd., New York, NY.

Quinlan, C. B. 2013. Optimisation of the food dairy coop supply chain. $\mathrm{PhD}$ Thesis, University College Cork, Ireland.

Radostits, O. M. 2000. Veterinary Medicine: A Textbook of the Diseases of Cattle, Sheep, Pigs, Goats and Horses. Saunders, Philadelphia, PA.

Shalloo, L., A. Cromie, and N. McHugh. 2014. Effect of fertility on the economics pasture-based dairy systems. Animal 8(Suppl. 1):222-231.
Shalloo, L., P. Dillon, M. Rath, and M. Wallace. 2004. Description and validation of the Moorepark Dairy Systems Model. J. Dairy Sci. $87: 1945-1959$.

Shalloo, L., A. Ryan, and P. French. 2012. Getting ready for Expansion! Lessons from the Greenfield project. Pages 9-22 in Proc. Teagasc National Dairy Conference: Is Ireland ready for more milk? Tralee, Ireland. Accessed Jan. 10, 2014. http://www.teagasc.ie/ publications/2012/1607/National_Dairy_Conference_2012.pdf.

Taylor, D. W., G. Caldow, D. J. Brown, I. Riddel, and C. Dean. 2001 Salmonella enterica subspecies enterica serotype Montevideo as a cause of significant foetal loss and cow mortality in a beef herd. Cattle Pract. 9:217-222.

Teagasc. 2013. Teagasc management data for farm planning 2013/2014 Teagasc, Oakpark, Co. Carlow, Ireland.

Visser, S. C., J. Veling, A. A. Dijhuizen, and R. B. M. Huirne. 1997. Economic losses due to Salmonella Dublin in dairy cattle. Pages 143-151 in Proc. Dutch/Danish Symp. Anim. Health Econ. A. R. Kristensen, ed. Royal Veterinary and Agricultural University, Copenhagen, Denmark.

Williams, D. J. L., C. S. Guy, J. M. McGarry, L. Tasker, R. F. Smith, K. MacEachern, P. J. Cripps, D. F. Kelly, and A. J. Trees. 2000. Neospora caninum-associated abortion in cattle: The time of experimentally induced parasitaemia during gestation determines foetal survival. Parasitology 121:347-358.

Wray, C., and W. J. Sojka. 1977. Reviews of the progress of dairy science: Bovine salmonellosis. J. Dairy Res. 44:383-425. 